\title{
A STUDY OF THE VARIATIONS IN THE MORPHOLOGY OF THE THYROID GLAND AND ITS SURGICAL CORRELATIONS
}

\section{Mitesh R Dave ${ }^{1}$, Jaba Rajguru *2, Dimpy Gupta ${ }^{3}$.}

${ }^{1}$ Associate Professor, Department Of Anatomy, Parul Institute of Medical Sciences \& Research, Parul University, Vadodara, Gujarat, India.

${ }^{* 2}$ Associate Professor, Department Of Anatomy, Parul Institute of Medical Sciences \& Research, Parul University, Vadodara, Gujarat, India.

${ }^{3}$ Assistant Professor, Department Of Anatomy, Parul Institute of Medical Sciences \& Research, Parul University, Vadodara, Gujarat, India.

\section{ABSTRACT}

Introduction: Being a highly vascular and one of the essential endocrine glands, the knowledge of the variations in the morphology of the thyroid gland stands an important role with respect to their identification, isolation or preservation, and prevention of any untoward complication during the surgeries around the neck region, thus increasing the chances of favourable surgical outcome.

Aim: The aim of the present study was to identify the frequent variants in the structure of the thyroid gland, and to compare the same with the work of other authors.

Materials and Methods: The present study was conducted on total 86 thyroid glands with morphological variations, out of which 42 were of males and 44 were of females. These were obtained during routine dissection of the neck in the adult human cadavers aged above 50 years.

Results: The most common variation in the present study was the presence of pyramidal lobe $(50 \%$ in males and $65.9 \%$ in females), followed by the levator glandulae thyroidae (45.2\% in males and $52.3 \%$ in females), absence of the isthmus ( $7.1 \%$ in males and $20.5 \%$ in females), accessory thyroid tissue $(2.4 \%$ in males and $2.8 \%$ in females), and the least common was presence of groove in the thyroid tissue ( $0 \%$ in males and $2.8 \%$ in females). There were also combination of variants in some thyroids.

Conclusion: The study emphasizes on the common anatomical variations in the thyroid gland morphology and their surgical correlations.

KEY WORDS: Variations, Morphology, Thyroid gland, Pyramidal lobe, Levator glandulae thyroidae, Isthmus.

Address for Correspondence: Jaba Rajguru, Associate Professor, Department Of Anatomy, Parul Institute of Medical Sciences \& Research, Parul University, P.O.: Limda, Tal.: Waghodia, Dist.: Vadodara, Gujarat, India. E-Mail: hibiscusemily@yahoo.com

Access this Article online

Quick Response code

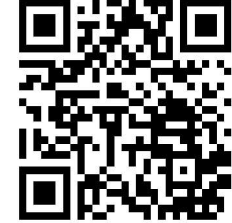

DOI: $10.16965 /$ ijar.2018.455

Journal Information

International Journal of Anatomy and Research

ICV for 2016
90.30 ISSN (E) 2321-4287 | ISSN (P) 2321-8967

https://www.ijmhr.org/ijar.htm DOI-Prefix: https://dx.doi.org/10.16965/ijar

\section{Article Information}

Received: 28 Dec 2018

Peer Review: 28 Dec 2018

Revised: None
Accepted: 12 Feb 2019

Published (O): 05 Mar 2019

Published (P): 05 Mar 2019

\section{INTRODUCTION}

The thyroid gland is situated low down at the front of the neck. It consists of two symmetrical lobes united by an isthmus that lies in front of the second, third and fourth tracheal rings. The isthmus joins the anterior parts of the lobes, towards their lower poles. A small portion of gland substance often projects upwards from the isthmus, generally to the left of the midline, as 
the pyramidal lobe and represents a development of glandular tissue from the caudal end of the thyroglossal duct. It may be attached to the inferior border of the hyoid bone by fibrous tissue; muscle fibres sometimes present in it are named levator glandulae thyroidae [1].

Most of the variations in the morphology of the thyroid gland are related to its development. This may lead to various thyroid disorders, some of which may require surgical correction. Thus a knowledge of these variations is essential during different types of thyroidectomies and surgeries in the neck region [2].

Aims: The aims of the present study were to identify and tabulate the frequency of incidence of the various morphological variations in the thyroid gland, and to compare the results with those of previous studies.

\section{MATERIALS AND METHODS}

The present observational study was conducted on total 86 thyroid glands, out of which 42 were of males and 44 were of females. These were obtained during routine dissection of the neck in the adult human cadavers aged above 50 years, during period from October 2015 to September 2018 at Parul University, Vadodara, Gujarat, India.

The variants studied were - presence of pyramidal lobe; its attachment to either lobes/ isthmus, presence of levator glandulae thyroidae; its attachment to hyoid bone/lobes or isthmus, absence of isthmus, presence of accessory thyroid tissues and presence of grooves on the surface of thyroid tissue.

The study was ethically approved by the ethical committee of the Parul Institute of Medical Sciences \& Research, Parul University.

Table 1: Different morphological variations observed in male and female thyroid glands.

\begin{tabular}{|l|c|c|c|c|}
\hline \multicolumn{1}{|c|}{ Morphological Variation } & Male $(\mathrm{n})$ & Male (\%) & Female $(\mathrm{n})$ & Female (\%) \\
\hline Pyramidal lobe & 21 & 50 & 29 & 65.9 \\
\hline Levator glandulae thyroidae & 19 & 45.2 & 23 & 52.3 \\
\hline Absence of isthmus & 3 & 7.1 & 9 & 20.5 \\
\hline Groove in thyroid tissue & 0 & 0 & 1 & 2.8 \\
\hline Accessory thyroid tissue & 1 & 2.4 & 1 & 2.8 \\
\hline
\end{tabular}

Out of the 86 thyroid glands that were collected having some or other morphological variation, from 42 male and 44 female cadavers, the pyramidal lobe was reported in $50 \%$ male and $65.9 \%$ female specimens [Fig.1]. Levator glandulae thyroidae was seen in $45.2 \%$ male and $52.3 \%$ female specimens [Fig.1,2 and 3], absence of isthmus in $7.1 \%$ male and $20.5 \%$ female specimens [Fig.1 and 3], accessory thyroid tissue in $2.4 \%$ male and $2.8 \%$ female specimens [Fig.3] and the presence of groove in the thyroid tissue in 1 female specimen [Fig.3].

More than one variation (combination of two or more) in a thyroid gland was reported in $16.7 \%$ male and $25 \%$ female specimens.

Fig. 1: Showing RL=Right lobe; LL=Left lobe; PL=Pyramidal lobe; Arrow 1= Levator glandulae thyroidae attached to pyramidal lobe (arising from left lobe) and hyoid bone; Arrow 2= Levator glandulae thyroidae arising directly from right lobe, and attached to thyroid cartilage; *= Absence of isthmus.

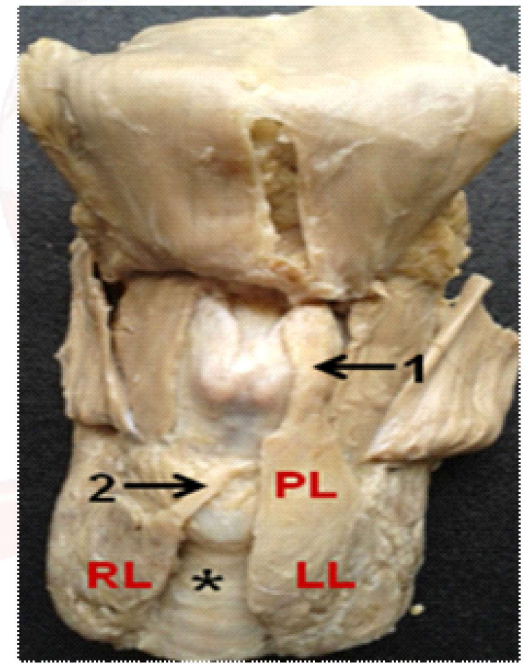

Fig. 2: Showing RL=Right lobe; LL=Left lobe; I=Isthmus; Arrow = Levator glandulae thyroidae arising directly from left lobe, with some fibres attached to thyroid cartilage.

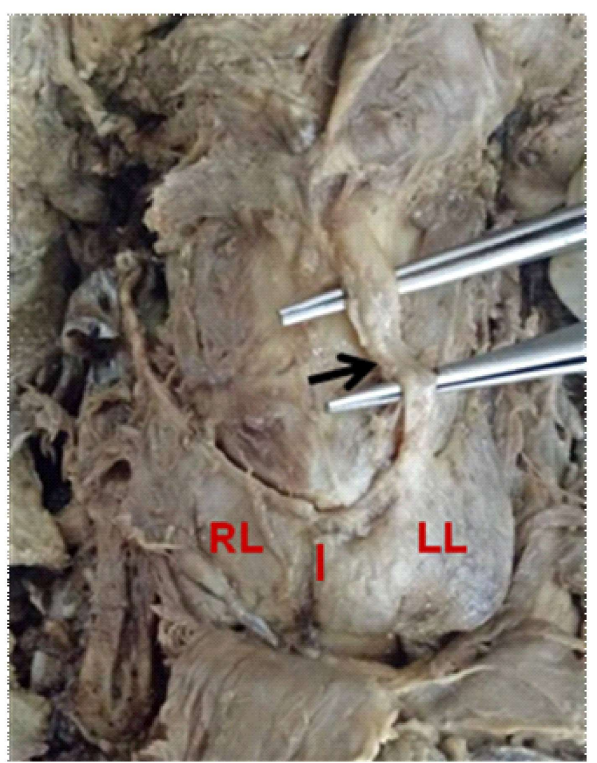


Fig. 3: Showing arrow 1= Levator glandulae thyroidae arising from upper border of left side of isthmus, and attached to thyroid cartilage; Arrow 2= Accessory thyroid tissue; ${ }^{*}=$ Agenesis of lower part of isthmus; Forceps pointing to the presence of groove in the thyroid lobe.

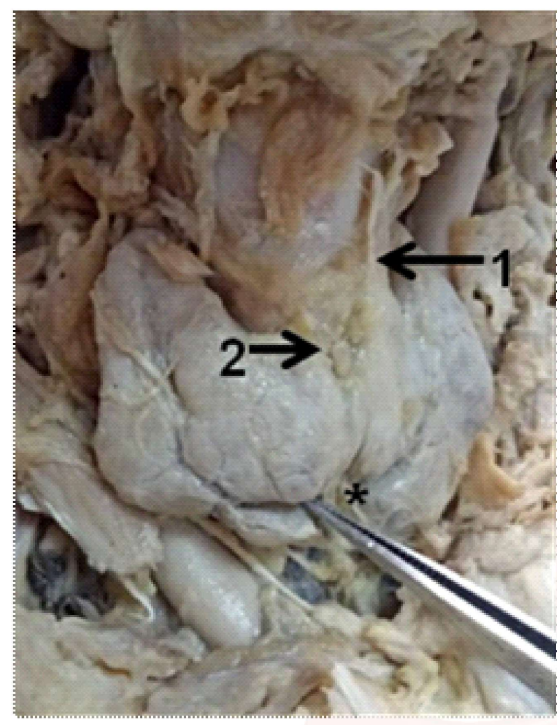

\section{DISCUSSION}

The various variations in the morphology of the thyroid gland reported in the present study were compared with those of the previous studies. [Table 2]
The most common morphological variation in the thyroid gland reported in the previous studies was the presence of pyramidal lobe, followed by the presence of levator glandulae thyroidae, and absence of the isthmus. Out of these, most of the thyroids had combination of two or more variants in one specimen, the commonest being the presence of pyramidal lobe and levator glandulae thyroidae. Accessory thyroid tissue was also reported by Ranade $A \mathrm{~V}$ et al (0.95\% specimens), Veerahanumaiah $S$ et al (2.24\% specimens) and Gaikwad S et al $(1.6 \%$ specimens).

In addition to above studies, some authors also published such variations in the cadavers as case reports. Praveen Kumar G. Et al reported agenesis of isthmus of the thyroid gland with pyramidal lobe and levator glandulae thyroidae arising from the right lobe [19]. Chaudhary $P$ et al reported a rare case of levator glandulae thyroidae arising from the upper border of the left side of isthmus (pyramidal lobe being absent) and attaching to the hyoid bone above [20]. Nikumbh R D et al reported two cases;

Table 2: Comparison of 3 frequent variants observed in the present study with the previous studies.

\begin{tabular}{|c|c|c|c|c|c|}
\hline Author & $\begin{array}{l}\text { Year of } \\
\text { study }\end{array}$ & $\begin{array}{l}\text { Sample } \\
\text { size }\end{array}$ & $\begin{array}{l}\% \text { presence of } \\
\text { pyramidal lobe }\end{array}$ & $\begin{array}{l}\% \text { presence of levator } \\
\text { glandulae thyroidae }\end{array}$ & $\begin{array}{c}\% \text { absence of } \\
\text { isthmus }\end{array}$ \\
\hline Ranade A V et al [3] & 2008 & 105 & 58 & 49.5 & 33 \\
\hline Sultana S Z et al [4] & 2009 & 60 & 84.65 & 43.33 & - \\
\hline Dixit D et al [5] & 2009 & 41 & 7.31 & 7.31 & 14.6 \\
\hline Joshi S D et al [6] & 2010 & 90 & 37.77 & 30 & 16.66 \\
\hline Zivic $R$ et al [7] & 2011 & 100 & 61 & - & - \\
\hline Prakash et al [8] & 2012 & 70 & 38.57 & 32.86 & 8.57 \\
\hline Kulkarni V et al [9] & 2012 & 20 & - & 30 & 10 \\
\hline Milojevic B et al [10] & 2013 & 58 & 55.2 & - & - \\
\hline Veerahanumaiah S et al [11] & 2015 & 89 & 46 & 41 & 9 \\
\hline Hussain Kafeel A et al [12] & 2015 & 32 & 40.6 & 25 & 6.2 \\
\hline Rathod M S et al [13] & 2015 & 76 & 58 & - & 13 \\
\hline Rajkonwar A J et al [14] & 2016 & 80 & 38.75 & 18.75 & 21.25 \\
\hline Gaikwad S et al [15] & 2016 & 100 & 26.59 & 30.85 & 29.78 \\
\hline Das S R et al [16] & 2018 & 32 & 12.5 & 17.5 & 12.5 \\
\hline Movya Venkata Vinaya Kumar et al [17] & 2018 & 60 & 13.3 & 5 & 8.3 \\
\hline Surya Venkata Narayana P. et al [18] & 2018 & 25 & 8 & 12 & 4 \\
\hline Present study & 2018 & 86 & 58.1 & 48.8 & 13.9 \\
\hline
\end{tabular}

in first, there was absence of isthmus, presence of the accessory thyroid lobe in between two lateral lobes, presence of left pyramidal lobe and presence of levator glandulae thyroidae on left side; in the second, there was presence of narrow isthmus related to first tracheal ring and presence of levator glandulae thyroidae arising from the left lobe of thyroid gland [21].

In the present study, we also observed accessory thyroid tissue $(2.4 \%$ in male and $2.8 \%$ in 
female specimens), and the presence of groove in the thyroid tissue ( $0 \%$ in male and $2.8 \%$ in female specimens).

The common variants like the pyramidal lobe, levator glandulae thyroidae and the absence of isthmus are mainly due to anomalies during the development of the thyroid gland. The thyroid gland appears as an epithelial proliferation in the floor of the pharynx from the foramen caecum in the form of bilobed diverticulum, called the thyroglossal duct. The lower part of the duct develops in to median isthmus and two lateral lobes. The upper connection of the duct with the floor of pharynx later disappears. A high division of the thyroglossal duct can result in two independent thyroid lobes and no isthmus [22]. During the development of thyroid gland, positional variation and the ultimate position of the thyroid gland depends on extent of elongation of thyroglossal duct [23]. According to Moore and Persaud, pyramidal lobe is seen in $50 \%$ of population and the muscular band may be made up of smooth muscle fibres and that the pyramidal lobe and the associated smooth muscle represent the persistent part of distal end of thyroglossal duct [24].

The surgeon should keep the morphological variations in mind during different types of thyroidectomies $[25,26]$. The knowledge of such variations would increase the chances of favourable surgical outcome.

\section{CONCLUSION}

The present study emphasizes on the common anatomical variations in the thyroid gland morphology, an accurate knowledge of which is important for the surgeons to perform safe and effective surgery.

\section{Conflicts of Interests: None}

\section{REFERENCES}

[1]. Sinnatamby CS. Last's Anatomy: Regional and Applied. 12th Ed. Churchill Livingstone. P-339.

[2]. Raut RS, Jadhav SS, Kulkarni PR. Morphometric study of pyramidal lobe and levator glandulae thyroidae and its surgical significance. Int J Anat Res. 2018;6(3.2):5538-43

[3]. Ranade AV, Rai R, Pai MM, Nayak SR, Prakash, Krisnamurthy A, Narayana S. Anatomical variations of the thyroid gland: possible surgical implications. Singapore Med J. 2008;49(10):831-834.
[7]. Zivic R, Radovanovic D, Vekic B, Markovic I, Dzodic $\mathrm{R}$, Zivaljevic V. Surgical anatomy of the pyramidal lobe and its significance in thyroid surgery. S Afr J Surg. 2011;49(3):110-14.

[8]. Prakash, Rajini T, Ramachandran A, Savalgi GB, Venkata SP, Mokhasi V. Variations in the anatomy of the thyroid gland: clinical implications of a cadaver study. Anat Sci Int. 2012;87(1):45-9.

[9]. Kulkarni V, Sreepadma S, Deshpande SK. Morphological variations of the thyroid gland. Medica Innovatica. 2012;1(2):35-38.

[10]. Milojevic B, Tosevski J, Milisavljevic M, Babic D, Malikovic A. Pyramidal lobe of the human thyroid gland: an anatomical study with clinical implications. Rom J Morphol Embryol. 2013;54(2):285-9.

[11]. Veerahanumaiah S, Dakshayani KR, Menasinkai SB. Morphological variations of the thyroid gland. Int J Res Med Sci. 2015;3(1):53-57.

[12]. Kafeel Hussain A, Sujatha N, Kommuru H, Prasad B, SwayamJothi. Morphological variations of the thyroid gland. IOSR-JDMS. 2015;14(3):18-24.

[13]. Rathod S Mansing, Taru MS, Sawai SD. Morphological variations of thyroid gland. International J of Healthcare and Biomedical Research. 2015;3(2):175-177.

[14]. Rajkonwar AJ, Kusre G. Morphological variations of the thyroid gland among the people of upper Assam region of northeast India: a cadaveric study. J Clin Diagn Res. 2016;10(12):AC01-AC03.

[15]. Gaikwad S, Joshi R. An anatomical study of morphological variations of the thyroid gland. Int J Anat Res. 2016;4(3):2665-69.

[16]. Das SR, Champatyray S, Nayak GR, Mohanty BB. Study of morphological variations of thyroid gland in adult human cadavers. J. Evolution Med. Dent. Sci. 2018;7(23):2807-2810.

[17]. Movya Venkata Vinaya Kumar, Reshma Mohammad, Sreelatha S. Possible variations of thyroid gland: a detailed cadaveric study. International Journal of Anatomy, Radiology and Surgery. 2018;7(2):A009AO13.

[18]. Surya Venkata Narayana P, Nisha Parveen CB, Mayuri MVR, Deva Priyanka K. A study on morphological variations of thyroid gland. IOSR-JDMS. 2018;17(7):49-53.

[19]. Kumar GP, Satyanarayana N, Vishwakarma N, Guha $R$, Dutta AK, Sunitha P. Agenesis of isthmus of thyroid gland, its embryological basis and clinical significance - A case report. Nepal Med Coll J. 2010;12(4):272-274.

[20]. Chaudhary P, Singh Z, Khullar M, Arora K. Levator glandulae thyroidae, a fibromuscular band with absence of pyramidal lobe and its innervations: A case report. J. Clin Diagn Res. 2013;7(7):1421-4.

[21]. Nikumbh RD, Nikumbh DB, Doshi MA. Multiple morphological variations in the thyroid gland: Report of two cases. Int J Anat Res. 2015;3(4):1476-80.

[22]. Saddler TW. Langman's Medical Embryology, Thyroid gland. 11th Ed. Lippincott Williams and Wilkins. 2010;p 278 
[23]. Larsen WJ. Development of the head and neck; In: Larsen WJ, ed. Human Embryology. New York: Churchill Livingstone. 1993;335-39.

[24]. Moore KL, Persaud TVN. The Developing Human, Clinically Oriented Embryology. 6th Ed. Philadelphia, W.B. Saunders Copmany. 2003;230-3.

[25]. Sinos G, Sakorafas GH. Pyramidal lobe of the thyroid: anatomical considerations of importance in thyroid cancer surgery. Oncol Res Treat. 2015;38(6):309-10.
[26]. Gurleyik E, Gurleyik G, Dogan S, Cobek U, Cetin F, Onsal U. Pyramidal lobe of the thyroid gland: Surgical anatomy in patients undergoing total thyroidectomy. Anat Res Int. 2015;3841-48.

How to cite this article:

Mitesh R Dave, Jaba Rajguru, Dimpy Gupta. A STUDY OF THE VARIATIONS IN THE MORPHOLOGY OF THE THYROID GLAND AND ITS SURGICAL CORRELATIONS. Int J Anat Res 2019;7(1.3):62696273. DOI: 10.16965/ijar.2018.455 